\title{
Reversal of Clozapine Effects on Working Memory in Rats with Fimbria-Fornix Lesions
}

\author{
Nii A Addy', Ana Pocivavsek' and Edward D Levin*,' \\ 'Department of Psychiatry and Behavioral Sciences, Duke University Medical Center, Durham, NC, USA
}

\begin{abstract}
Clozapine is an effective antipsychotic drug, but its effects on cognitive function are unclear. Previously, we found that clozapine caused a working memory deficit, which was reversed by nicotine. Hippocampal systems are important in determining clozapine effect on memory. In the current study, the memory effects of clozapine and nicotine administration were determined in rats with lesions of the fimbria-fornix, a fiber bundle which carries cholinergic and other projections between the septum and the hippocampus. Female Sprague-Dawley rats were trained on a win-shift procedure in the radial-arm maze, in which each arm entry was rewarded once per session. Then, 13 rats received bilateral knife-cut lesions of the fimbria-fornix, while 14 rats underwent sham surgery. The rats were tested after subcutaneous injections with combinations of clozapine $(0$ and $1.25 \mathrm{mg} / \mathrm{kg})$ and nicotine $(0,0.2$, and $0.4 \mathrm{mg} / \mathrm{kg})$. In shamoperated rats, clozapine caused a significant $(P<0.005)$ working memory impairment. Fimbria-fornix lesions also caused a significant $(P<0.05)$ memory impairment. Interestingly, clozapine had the opposite effect on working memory in the lesioned vs sham-operated rats. In contrast to its effects in controls, clozapine $(1.25 \mathrm{mg} / \mathrm{kg})$ significantly $(P<0.05)$ attenuated the working memory deficit caused by fimbria-fornix lesions. Nicotine $(0.2 \mathrm{mg} / \mathrm{kg})$ did not quite significantly improve memory in lesioned rats. The effects of clozapine and nicotine were not additive in the lesioned rats. This study demonstrates the efficacy of clozapine in improving working memory in fimbria-fornix-lesioned rats, whereas it causes impairments in intact rats. Therapeutic treatment with clozapine in people with malfunctions of the hippocampus such as seen in schizophrenia may improve cognitive performance, whereas the same doses of clozapine may impair memory in individuals without hippocampal malfunction.

Neuropsychopharmacology (2005) 30, I I 2 I - I I27, advance online publication, 26 January 2005; doi: 10.1038/sj.npp. 1300669
\end{abstract}

Keywords: clozapine; nicotine; fimbria-fornix; hippocampus; memory; radial-arm maze

\section{INTRODUCTION}

Cognitive impairment in schizophrenia is pronounced and includes deficits in attention and memory function (Cornblatt and Keilp, 1994; Gallhofer et al, 1996; Sharma and Mockler, 1998; Stip, 1996; Tollefson, 1996). Such impairments appear to be a core feature of schizophrenia (Weinberger and Gallhofer, 1997), but are exacerbated by classic antipsychotic drugs (Gallhofer et al, 1996; Levin et al, 1996; Stip, 1996). The cognitive effects of atypical antipsychotics such as clozapine may hold promise for improvements in cognitive function; however, the current data regarding clozapine effects on cognitive function are mixed (Hoff et al, 1996; Tollefson, 1996). Some studies of

\footnotetext{
*Correspondence: Dr ED Levin, Department of Psychiatry and Behavioral Sciences, Neurobehavioral Research Laboratory, Box \#34 I2, Duke University Medical Center, Durham, NC 27710, USA, Tel: + 1919681 6273, Fax: + | 9196813412 ,

E-mail: edlevin@duke.edu

Received 28 July 2004; revised and accepted 2 December 2004 Online publication: I 5 December 2004 at http://www.acnp.org/citations/ Npp 12 I 504040344/default.pdf
}

people with schizophrenia have shown clozapine-induced cognitive improvements in attentional tasks (Gallhofer et al, 1996; Hagger et al, 1993; Lee et al, 1999; Manschreck et al, 1999; McGurk, 1999; Meltzer and McGurk, 1999; Sharma and Mockler, 1998). Other clinical studies, however, have demonstrated clozapine-induced memory deficits (Goldberg et al, 1993; Goldberg and Weinberger, 1996). Furthermore, rodent studies have shown clozapine-induced memory impairments in intact rats (Addy and Levin, 2002; Skarsfeldt, 1996).

In discussing memory performance in the schizophrenic population, one must consider the effects of nicotine and antipsychotic co-administration, since a great majority of these individuals smoke cigarettes and thus self-administer nicotine (Herran et al, 2000; Hughes et al, 1986). They may be self-medicating to combat cognitive impairments that result both from schizophrenia itself and from antipsychotic drug treatment. We have found that people with schizophrenia have significant nicotine-induced improvements in attentional performance when nicotine is administered via skin patch treatment (Levin et al, 1996). Nicotine treatment also significantly reduced impairments in memory and 
information-processing speed caused by haloperidol, a typical antipsychotic drug (Levin et al, 1996).

Chronic and acute nicotine administration improves working memory performance in rats tested on a radialarm maze (Bancroft and Levin, 2000; Levin and Simon, 1998). These nicotine-induced improvements are blocked by the nicotinic antagonist mecamylamine (Levin and Simon, 1998). Nicotine acts directly by stimulating nicotinic acetylcholine receptors and also promotes the release of downstream neurotransmitters including dopamine and serotonin (Wonnacott et al, 1989). These nicotinic receptors are located in a variety of brain regions including the prefrontal cortex and the hippocampus, both of which are important for memory function (Goldman-Rakic, 1996; Jarrard, 1993; Laroche et al, 2000). We have shown that nicotinic receptors in the hippocampus are important for memory performance as local hippocampal infusion of nicotinic receptor antagonists significantly impairs memory function (Arthur and Levin, 2002; Bancroft and Levin, 2000; Bettany and Levin, 2001; Felix and Levin, 1997; Kim and Levin, 1996; Levin et al, 2002).

Hippocampal involvement in memory function has also been demonstrated through lesions of the fimbria-fornix, which normally relays hippocampal output to the septum. Fimbria-fornix lesions have been repeatedly shown to cause pronounced memory impairments (Levin et al, 1999a; Balse et al, 1999; Levin et al, 1993). These fimbria-fornix lesioninduced impairments can be reversed by chronic nicotine infusion (Levin et al, 1993). Ibotenic acid lesions of the hippocampus have been shown to block chronic nicotineinduced memory improvement (Levin et al, 1999b). Therefore, in fimbria-fornix-lesioned animals, nicotine may be acting at intact postsynaptic receptors, which are damaged in ibotenic-acid-lesioned animals. Hippocampal lesions can be used to address the possible hippocampal involvement of nicotine and the effects of atypical antipsychotics on memory performance.

The aim of the current study was to examine hippocampal involvement in the effects of nicotine and clozapine, an atypical antipsychotic, on working memory performance in rats tested on the radial-arm maze. Previous work demonstrated clozapine-induced impairments that were reversed by nicotine coadministration (Addy and Levin, 2002). In the current work, we examined the possibility of hippocampal involvement in such mechanisms by comparing nicotine and clozapine effects on memory performance in rats with and without fimbria-fornix lesions.

\section{METHODS}

\section{Subjects}

A total of 27 female Sprague-Dawley rats were used in this experiment. The rats were housed three per cage and were on a reverse $12 \mathrm{~h} \mathrm{light} / 12 \mathrm{~h}$ dark cycle. The subjects were given ad lib feeding for 1 week and then kept at approximately $85 \%$ of free-feeding levels. Testing took place during the dark cycle. The rats were fed daily after testing. This study was conducted in compliance with the Guide for the Care and Use of Laboratory Animals and approval of the Duke University Animal Care and Use Committee.

\section{Radial-Arm Maze}

Cognitive tests were performed using a black, wooden eightarm radial maze. The maze was elevated $30 \mathrm{~cm}$ off the ground with a central platform $35 \mathrm{~cm}$ in diameter and eight arms each $10 \times 80 \mathrm{~cm}^{2}$. Each arm contained a food cup, at its terminal end, which was baited during testing with $1 / 2$ piece of Kellogg's Froot Loops ${ }^{\circledR}$ cereal. Then a $30-\mathrm{cm}$ opaque ring was placed on the central platform and a rat was placed inside the ring for $10 \mathrm{~s}$. Following this interval, the ring was removed and timing began. The rat was allowed to run on the maze until all eight arms were entered or until $300 \mathrm{~s}$ had passed. An arm entry was recorded when all four of the animal's legs had crossed the threshold of the arm. Choice accuracy was measured by entries to repeat, which was the number of arms entered until a repeat entry was made in the same arm. Latency was recorded as the total time divided by the number of entries. After 18 sessions of training that brought the rats to asymptotic levels of choice accuracy, the rats were divided into two groups matched for choice accuracy so that rats of comparable choice accuracy were put into two different surgery groups.

\section{Fimbria-Fornix Lesions}

Fimbria-fornix lesions were performed on approximately half of the rats, while the other rats received sham lesion treatment. The rats were anesthetized with an i.p. injection of ketamine $(75 \mathrm{mg} / \mathrm{kg})$ and medetomidine $(0.3 \mathrm{mg} / \mathrm{kg})$. The rats were then secured in the stereotaxic instrument. The rat's body temperature was maintained by an electric blanket. The bite bar was elevated at the head at an angle $5 \mathrm{~mm}$ above the intra-aural line. An incision was made extending from just behind the eyes to the front of the ears, exposing bregma. After bregma was marked, the targeted area for lesioning was determined using the measurements $\mathrm{A} / \mathrm{P}-0.06 \mathrm{~mm}, \mathrm{M} / \mathrm{L}+1.5$ to $+4.0 \mathrm{~mm}$. The skull was then drilled between these two markers to provide a cavity for the knife-cut lesion. Then the blade was lowered into the brain at one end of the cavity using the measurement $\mathrm{D} / \mathrm{V}$ $-4.5 \mathrm{~mm}$ from the dura. To lesion the fimbria-fornix, the knife was moved from one end of the cavity to the other and then lifted out of the skull. The procedure was then repeated on the opposite side of the brain. After both sides had been lesioned, the incision was sutured and the animal was revived with an i.p. injection of antisedan $(0.3 \mathrm{mg} / \mathrm{kg})$. Rats in the control sham-lesioned group underwent identical surgical procedures, except that the knife blade was not lowered. After the end of the study, the rats were killed and the brains were examined using histological sectioning and microscopic examination of the extent of the knife-cut lesion tract. It was documented that that the lesions were correctly placed for transecting the fimbria-fornix.

\section{Drug Administration}

Starting one week after surgery, each rat received acute injections (SC, injection volume $1 \mathrm{ml} / \mathrm{kg}$ ) of the drug combinations $20 \mathrm{~min}$ prior to testing on the radial-arm maze. Drugs were administered every other day to allow for washout. Clozapine (Research Biochemical International) 
and nicotine ditartrate (Sigma) were dissolved in saline, which served as the vehicle, and were injected in combined mixtures. Clozapine $\mathrm{HCl}$ was injected at doses of 0 or $1.25 \mathrm{mg} / \mathrm{kg}$, while nicotine was injected at doses of $0,0.2$ or $0.4 \mathrm{mg} / \mathrm{kg}$. The solutions were acidified with $0.1 \mathrm{M} \mathrm{HCl}$ to enhance solubility and $0.1 \mathrm{M} \mathrm{NaOH}$ was used to rebalance the $\mathrm{pH}$ to a target of 7 . The doses were calculated as a function of the salt. The six resulting drug combinations were administered in a repeated-measure counterbalanced order.

\section{Data Analysis}

The choice accuracy and response latency measures were assessed by a mixed between- and within-subjects design ANOVA. The between subjects factors were lesion (sham lesion $v s$ fimbria-fornix lesion) and the cohorts of rats (each of the three cohorts included sham-lesioned and lesioned rats). The total $N$ was 27 (14 sham and 13 lesioned). The within-subjects factors were nicotine and clozapine administration. A $p$-value of less than 0.05 (two-tailed) was considered significant. Planned comparisons were made between the sham lesion + vehicle condition and the fimbria-fornix lesion + vehicle condition, as well as with the sham lesion + each of the drug treatments and between the fimbria-fornix lesion + vehicle condition and each of the drug treatment conditions within the lesioned groups.

\section{RESULTS}

\section{Choice Accuracy}

There was a significant clozapine $\times$ lesion interaction $(\mathrm{F}(1,21)=8.76, p<0.01)$. As shown in Figure 1, clozapine had opposite effects on working memory performance in rats with sham lesions and those with fimbria-fornix lesions. With the sham-operated rats, there was a significant $(\mathrm{F}(1,11)=10.36, p<0.01)$ clozapine-induced memory deficit. With $1.25 \mathrm{mg} / \mathrm{kg}$ clozapine, the rats averaged $4.81 \pm 0.31$ entries to repeat, while without clozapine they averaged $5.93 \pm 0.37$ entries to repeat. Nicotine cotreatment was not seen to alter this effect in this study. The opposite effect was seen in the rats with fimbria-fornix lesions; $1.25 \mathrm{mg} / \mathrm{kg}$ clozapine given alone significantly $(\mathrm{F}(1,10)=7.58, p<0.025)$ improved the working memory performance from $4.31 \pm 0.28$ with saline injections to $5.54 \pm 0.37$ with $1.25 \mathrm{mg} / \mathrm{kg}$ clozapine. Nicotine cotreatment did not potentiate this improvement. Rather, nicotine cotreatment reduced the beneficial effect of clozapine such that with the $0.4 \mathrm{mg} / \mathrm{kg}$ nicotine dose and $1.25 \mathrm{mg} / \mathrm{kg}$ clozapine the choice accuracy performance was only $4.94 \pm 0.33$ entries to repeat.

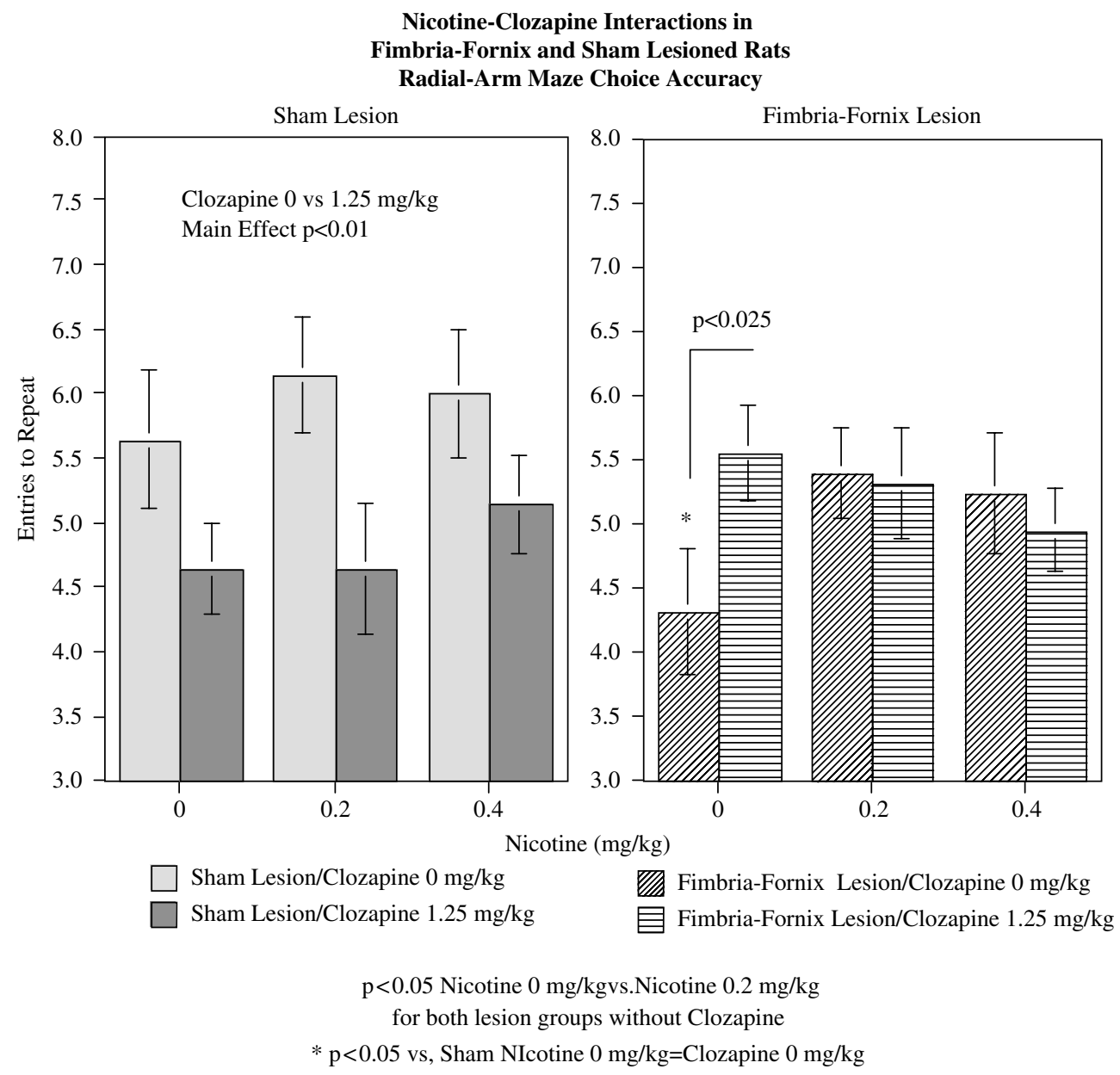

Figure I Choice accuracy (entries to repeat) with nicotine and clozapine treatment in rats with fimbria-fornix and sham lesions (mean \pm SEM). 


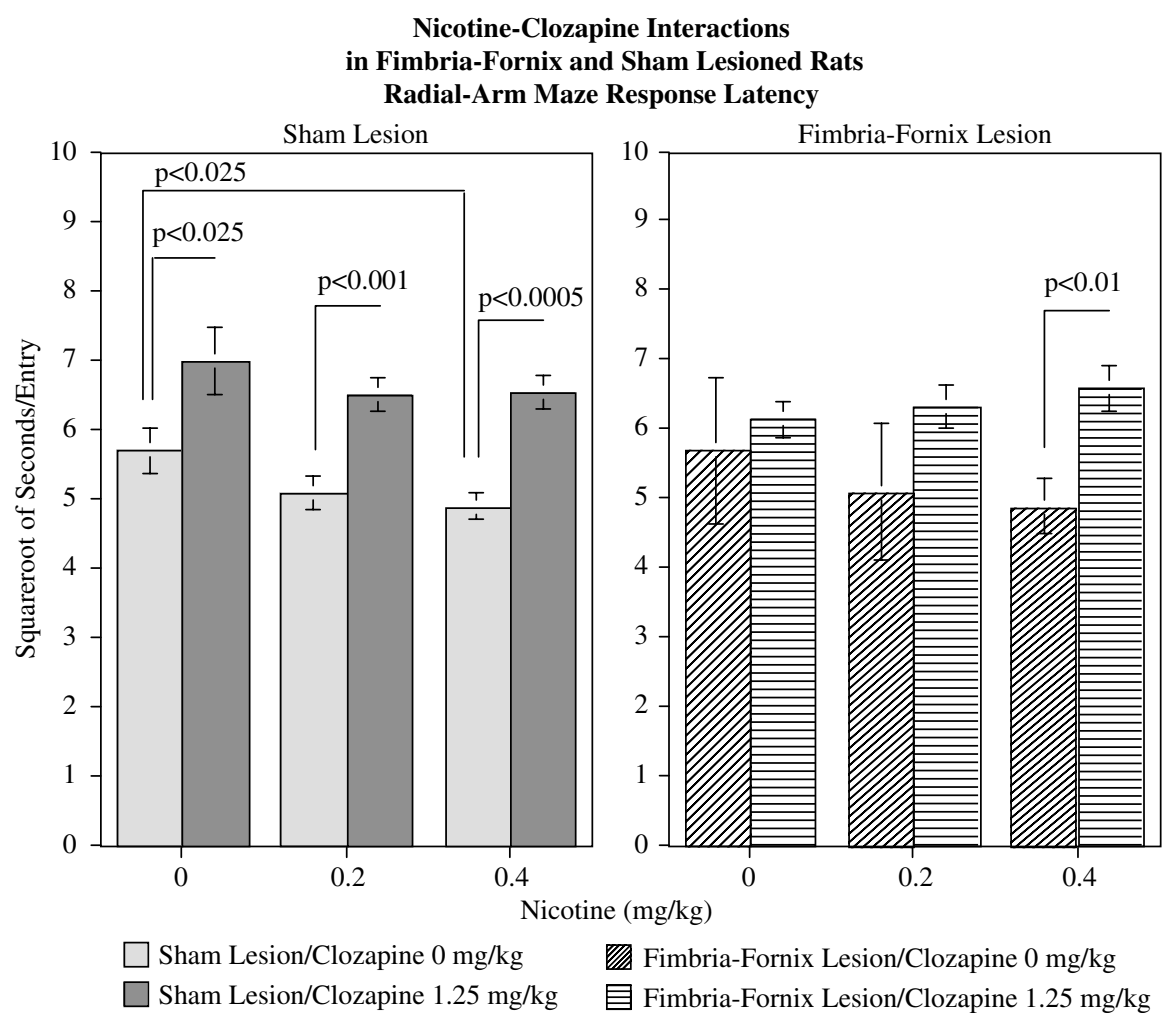

Figure 2 Choice latency (seconds per entry) with nicotine and clozapine treatment in rats with fimbria-fornix and sham lesions (mean \pm SEM).

\section{Response Latency}

There was a significant $(\mathrm{F}(1,21)=6.62, p<0.025)$ clozapine $\times$ lesion interaction with response latency. The shamoperated rats had a significant $(\mathrm{F}(1,11)=41.89, p<0.001)$ clozapine-induced slowing of response from $28.2 \mathrm{~s}$ per entry without clozapine to $45.9 \mathrm{~s}$ per entry with $1.25 \mathrm{mg} / \mathrm{kg}$ of clozapine. As shown in Figure 2, clozapine caused significant increases in latency in the sham-operated group when administered alone $(p<0.025)$ or in conjunction with $0.2 \mathrm{mg} / \mathrm{kg}(p<0.001)$ or $0.4 \mathrm{mg} / \mathrm{kg}$ of nicotine $(p<0.0005)$. The higher nicotine dose also was seen to significantly $(p<0.025)$ lower the response latency in the sham-operated group. This nicotine effect on latency was clearly significant, but was modest in extent. In contrast, in the rats with fimbria-fornix lesions, the only significant clozapine increase in latency was seen when clozapine was given together with $0.4 \mathrm{mg} / \mathrm{kg}$ of nicotine $(p<0.01)$, and no nicotine effects on response latency were seen.

\section{DISCUSSION}

The results illustrate the differential memory effects of clozapine in fimbria-fornix-lesioned $v s$ nonlesioned rats. Clozapine impaired memory in nonlesioned rats, whereas it significantly attenuated the memory impairment caused by fimbria-fornix lesions. Acute nicotine administration did not significantly interact with these effects, though there was a higher average memory performance level with nicotine treatment in the lesioned animals. The clozapineinduced memory impairment in intact rats replicated our earlier study showing this effect in the radial-arm maze
(Addy and Levin, 2002), as well as a complementary finding showing attentional impairment in rats given clozapine, in the same dose range (Rezvani et al, 2004). The fimbriafornix lesion-induced working memory impairment also replicated earlier findings (Levin et al, 1999a, 1993). The most important finding of the current study was that not only was the clozapine-induced memory impairment eliminated by the fimbria-fornix lesion, but also that clozapine treatment reversed the memory impairment caused by this lesion.

\section{Clozapine Effects at Diverse Receptors}

Clozapine has antagonistic effects at a variety of transmitter receptors important for memory function, including dopaminergic, serotonergic and muscarinic acetylcholinergic receptors. All of these actions may underlie the differential effects of clozapine in rats with and without fimbria-fornix lesions.

One of the most critical effects of clozapine with regard to memory function may be its antagonism of muscarinic acetylcholinergic receptors (Michal et al, 1999). Muscarinic receptors, particularly those in the hippocampus (Kim and Levin, 1996; Ohno et al, 1994), are critically important for working memory function. The fimbria-fornix lesion interrupts the cholinergic innervation of the hippocampus from the septum. The reversal of clozapine effects on memory in rats with fimbria-fornix lesions may have been due to this interruption of the cholinergic innervation of hippocampal muscarinic receptors, obviating the muscarinic antagonist effects of clozapine in the hippocampus. 
Other receptor subtypes are also implicated in the mechanism of clozapine-induced modulation of memory performance. Like many of the typical antipsychotic medications, clozapine acts as an antagonist at the $\mathrm{D}_{2}$ dopaminergic receptor (Burns, 2001). In contrast to typical antipsychotics, clozapine also blocks $\mathrm{D}_{4}$ receptors and 5$\mathrm{HT}_{2}$ serotonergic receptors (Burns, 2001; Matsubara et al, 1993). Both $D_{2}$ and $D_{4}$ ligands have been shown to significantly affect memory performance (Bernaerts and Tirelli, 2003; Levin, 1997; Levin et al, 1996; McGurk et al, 1988). In previous work, we demonstrated that antagonism of $\mathrm{D}_{2}$ receptors in the ventral hippocampus by infusions of the $\mathrm{D}_{2}$ antagonist raclopride, causes working memory impairments in rats (Wilkerson and Levin, 1999). Umegaki et al (2001) have also demonstrated T-maze memory performance deficits after hippocampal infusion of $\mathrm{D}_{2}$ antagonists. $\mathrm{D}_{4}$ receptor antagonist effects of clozapine may contribute the differential effects seen in the fimbria-fornixlesioned and sham-operated rats in the current study. Zhang et al (2004) found that a selective $\mathrm{D}_{4}$ receptor antagonist impaired working memory performance in rats performing at high levels of accuracy, but improved working memory performance in rats with poor baseline performance levels. This is similar to the finding in the current study.

The serotonergic system has also been implicated in memory function. Several studies have demonstrated that either serotonin depletion or antagonism of serotonergic receptors leads to memory deficits, particularly in working memory (Cassaday et al, 2003; Lieben et al, 2004; Pache et al, 2003; Park et al, 1994; Porter et al, 2003).

Serotonergic receptors within the hippocampus, primarily $5 \mathrm{HT}_{1}$ subtype receptors, have also been shown to modulate memory performance (Buhot, 1997). Stimulation of $5-\mathrm{HT}_{1 \mathrm{~A}}$ or $5-\mathrm{HT}_{1 \mathrm{~B}}$ serotonergic receptors in the hippocampus impairs memory performance (Buhot et al, 1995; Warburton et al, 1997). Blockade of 5- $\mathrm{HT}_{1 \mathrm{~A}}$ receptors in the hippocampus, in contrast, has been shown to attenuate scopolamine-induced impairments in memory performance (Carli et al, 1997; Ohno and Watanabe, 1996). Clozapine has agonist effects at $5-\mathrm{HT}_{1 \mathrm{~A}}$ receptors (Chou et al, 2003) that may partially underlie its memory impairing effects in normal animals. Its antagonistic effects at $5-\mathrm{HT}_{2}$ receptors (Burns, 2001) may also contribute to this effect as well. Thus, we suggest clozapine activity in the hippocampus contributes to decreased working memory performance primarily through muscarinic cholinergic blockade, although dopaminergic antagonism and complex serotonergic effects may contribute as well.

\section{Lesions of the Fimbria-Fornix}

When the fimbria-fornix was lesioned, clozapine administration led to a working memory improvement, illustrating that clozapine can still modulate memory performance in the absence of the septo-hippocampal projection. We propose that the clozapine-induced improvement in working memory is due to clozapine activity in other regions of the brain outside the hippocampus. The prefrontal cortex, in particular, has been shown to be important for working memory performance (Goldman-Rakic, 1996). Thus, in the absence of the septohippocampal projection, clozapine effects in the prefrontal cortex could exert a larger influence on working memory and produce the clozapine-induced working memory improvement in lesioned animals. In support of this mechanism, clozapine has been shown to increase acetylcholine release in the hippocampus and prefrontal cortex, possibly due to presynaptic blockade of muscarinic acetylcholine receptors (Parada et al, 1997; Shirazi-Southall et al, 2002). In the prefrontal cortex, this clozapine-induced increase in acetylcholine is suggested to be related to 5 -HT receptor interactions (Ichikawa et al, 2002). Furthermore, this acetylcholine increase in the cortex has been observed during a working memory task (Hironaka et al, 2001). In rodent studies, aged mice show a decrease in cortical acetylcholine, which is accompanied by an increase in working memory errors (Ikegami, 1994). In monkeys, increases in cortical acetylcholine accompany working memory improvements (Tsukada et al, 2004). Given the literature and our results, we suggest that the clozapine-induced memory performance improvement in the fimbria-fornix-lesioned animals may result from clozapine-induced increases in cortical acetylcholine.

Acute nicotine treatment like acute clozapine showed an effect of reducing the fimbria-fornix lesion-induced memory impairment. However, coadministration of nicotine with clozapine in the lesion group did not further reduce the lesion-induced memory impairment. If anything, nicotine may have attenuated the beneficial effects of clozapine. Curiously, in the current study, nicotine did not attenuate the clozapine-induced memory impaired in the shamoperated group. Previously, in unoperated rats, we found that $0.4 \mathrm{mg} / \mathrm{kg}$ of nicotine effectively attenuated the memory impairment caused by $1.25 \mathrm{mg} / \mathrm{kg}$ of clozapine (Addy and Levin, 2002). In the current study, we did not find this effect. There was a slight increase in accuracy with $0.4 \mathrm{mg} /$ $\mathrm{kg}$ nicotine given to sham-operated rats with $1.25 \mathrm{mg} / \mathrm{kg}$ of clozapine, but this was not nearly significant. There may have been some carryover from the surgical procedure and anesthesia that attenuated the effect.

The fimbria-fornix lesions were used as a test of the role of septohippocampal connections in the effect of clozapine and nicotine. Hippocampal innervation, particularly cholinergic innervation, has been long known to be critically important for working memory function. Further studies will characterize the role of other areas in these effects of nicotine and clozapine on memory function. We felt that it was important to first characterize the effects of acute clozapine. Later studies will address the effects of chronic clozapine, which will provide a closer approximation to the clinical situation.

\section{Summary}

The current results show that the fimbria-fornix connections are important for the actions of clozapine on memory function. Clozapine impairs memory function in intact subjects. This effect appears to depend on the septohippocampal connections. Fimbria-fornix lesions not only blocked the clozapine-induced memory impairment, clozapine reversed the fimbria-fornix lesion-induced memory impairment to control levels of performance. This finding both adds to the basic understanding of the mechanisms of memory function and to the understanding of the clinical 
effects of clozapine on memory. In patients with schizophrenia who are given clozapine, the extent of hippocampal dysfunction may be critical in determining clozapine effects on cognition. Clozapine may be useful in attenuating cognitive impairment in people with hippocampal dysfunction, but may be contraindicated in those with intact hippocampal functioning because of cognitive impairment. Assessment of the regional integrity of brain function may be critical for determining optimal therapeutic drug treatment.

\section{ACKNOWLEDGEMENTS}

This work was supported by NIH grant MH64494.

\section{REFERENCES}

Addy N, Levin ED (2002). Nicotine interactions with haloperidol, clozapine and risperidone and working memory function in rats. Neuropsychopharmacology 27: 534-541.

Arthur D, Levin ED (2002). Chronic inhibition of alpha4beta2 nicotinic receptors in the ventral hippocampus of rats: impacts on memory and nicotine response. Psychopharmacology 160: 140-145.

Balse E, Lazarus C, Kelche C, Jeltsch H, Jackisch R, Cassel J (1999). Intrahippocampal grafts containing cholinergic and serotonergic fetal neurons ameliorate spatial reference but not working memory in rats with fimbria-fornix/cingular bundle lesions. Brain Res Bull 49: 263-272.

Bancroft A, Levin ED (2000). Ventral hippocampal alpha4beta2 nicotinic receptors and chronic nicotine effects on memory. Neuropharmacology 39: 2770-2778.

Bernaerts P, Tirelli E (2003). Facilitatory effect of the dopamine D4 receptor agonist PD168,077 on memory consolidation of an inhibitory avoidance learned response in C57BL/6J mice. Behav Brain Res 142: 41-52.

Bettany JH, Levin ED (2001). Ventral hippocampal alpha7 nicotinic receptors and chronic nicotine effects on memory. Pharmacol Biochem Behav 70: 467-474.

Buhot M, Patra S, Naili S (1995). Spatial memory deficits following stimulation of hippocampal 5-HT1B receptors in the rat. Eur $J$ Pharmacol 285: 221-228.

Buhot MC (1997). Serotonin receptors in cognitive behaviors. Curr Opin Neurobiol 7: 243-254.

Burns MJ (2001). The pharmacology and toxicology of atypical antipsychotic agents. J Toxicol Clin Toxicol 39: 1-14.

Carli M, Bonalumi P, Samanin R (1997). WAY 100635, a 5-HT1A receptor antagonist, prevents the impairment of spatial learning caused by intrahippocampal administration of scopolamine or 7-chloro-kynurenic acid. Brain Res 774: 167-174.

Cassaday H, Norman C, Shilliam C, Vincent C, Marsden C (2003). Intraventricular 5,7-dihydroxytryptamine lesions disrupt acquisition of working memory task rules but not performance once learned. Progr Neuro-Psychopharmacol Biol Psychiatry 27: 147-156.

Chou Y, Halldin C, Farde L (2003). Occupancy of 5-HT1A receptors by clozapine in the primate brain: a PET study. Psychopharmacology 166: 234-240.

Cornblatt BA, Keilp JG (1994). Impaired attention, genetics, and the pathophysiology of schizophrenia. Schiz Bull 20: 31-46.

Felix R, Levin ED (1997). Nicotinic antagonist administration into the ventral hippocampus and spatial working memory in rats. Neuroscience 81: 1009-1017.

Gallhofer B, Bauer U, Lis S, Krieger S, Gruppe H (1996). Cognitive dysfunction in schizophrenia: comparison of treatment with atypical antipsychotic agents and conventional neuroleptic drugs. Eur Neuropsychopharmacol 6: S13-S20.

Goldberg TE, Greenberg RD, Griffin SJ, Gold JM, Kleinman JE, Pickar D et al (1993). The effect of clozapine on cognition and psychiatric symptoms in patients with schizophrenia. $\mathrm{Br} J$ Psychiatry 162: 43-48.

Goldberg TE, Weinberger DR (1996). Effects of neuroleptic medications on the cognition of patients with schizophrenia: a review of recent studies. J Clin Psychiatry 57(Suppl 9): 62-65.

Goldman-Rakic P (1996). Regional and cellular fractionation of working memory. Proc Natl Acad Sci USA 93: 13473-13480.

Hagger C, Buckley P, Kenny JT, Friedman L, Ubogy D, Meltzer HY (1993). Improvement in cognitive functions and psychiatric symptoms in treatment-refractory schizophrenic patients receiving clozapine. Biol Psychiatry 34: 702-712.

Herran A, de Santiago A, Sandoya M, Fernandez MJ, DiezManrique JF, Vazquez-Barquero JL (2000). Determinants of smoking behaviour in outpatients with schizophrenia. Schizophr Res 41: 373-381.

Hironaka N, Tanaka K, Izaki Y, Hori K, Nomura M (2001). Memory-related acetycholine efflux from rat prefrontal cortex and hippocampus: a microdialysis study. Brain Res 901: 143-150.

Hoff AL, Faustman WO, Wieneke M, Espinoza S, Costa M, Wolkowitz O et al (1996). The effects of clozapine on symptom reduction, neurocognitive function, and clinical management in treatment-refractory state hospital schizophrenic inpatients. Neuropsychopharmacology 15: 361-369.

Hughes JR, Hatsukami DK, Mitchell JE, Dahlgren LA (1986). Prevalence of smoking among psychiatric outpatients. Am J Psychiatry 143: 993-997.

Ichikawa J, Dai J, O'Laughlin IA, Fowler WL, Meltzer HY (2002). Atypical, but not typical, antipsychotic drugs increase cortical acetylcholine release without an effect in the nucleus accumbens or striatum. Neuropsychopharmacology 26: 325-339.

Ikegami S (1994). Behavioral impairment in radial-arm maze learning and acetylcholine content of the hippocampus and cerebral cortex in aged mice. Behav Brain Res 65: 103-111.

Jarrard LE (1993). On the role of the hippocampus in learning and memory in the rat. Behav Neural Biol 60: 9-26.

Kim J, Levin E (1996). Nicotinic, muscarinic and dopaminergic actions in the ventral hippocampus and the nucleus accumbens: effects on spatial working memory in rats. Brain Res 725: 231-240.

Laroche S, Davis S, Jay T (2000). Plasticity at hippocampal to prefrontal cortex synapses: dual roles in working memory and consolidation. Hippocampus 10: 438-446.

Lee MA, Jayathilake K, Meltzer HY (1999). A comparison of the effect of clozapine with typical neuroleptics on cognitive function in neuroleptic-responsive schizophrenia. Schizophr Res 37: 1-11.

Levin ED (1997). Chronic haloperidol administration does not block acute nicotine-induced improvements in radial-arm maze performance in the rat. Pharmacol Biochem Behav 58: 899-902.

Levin ED, Bettegowda C, Blosser J, Gordon J (1999a). AR-R17779, and alpha7 nicotinic agonist, improves learning and memory in rats. Behav Pharmacol 10: 675-680.

Levin ED, Bradley A, Addy N, Sigurani N (2002). Hippocampal $\alpha 7$ and $\alpha 4 \beta 2$ nicotinic receptors and working memory. Neuroscience 109: $757-765$.

Levin ED, Christopher NC, Briggs SJ, Rose JE (1993). Chronic nicotine reverses working memory deficits caused by lesions of the fimbria or medial basalocortical projection. Cogn Brain Res 1: $137-143$

Levin ED, Christopher NC, Weaver T, Moore J, Brucato F (1999b). Ventral hippocampal ibotenic acid lesions block chronic nicotine-induced spatial working memory improvement in rats. Cogn Brain Res 7: 405-410. 
Levin ED, Simon BB (1998). Nicotinic acetylcholine involvement in cognitive function in animals. Psychopharmacology 138: 217-230.

Levin ED, Wilson W, Rose JE, McEvoy J (1996). Nicotinehaloperidol interactions and cognitive performance in schizophrenics. Neuropsychopharmacology 15: 429-436.

Lieben C, Oorsouw K, Deutz N, Blokland A (2004). Acute tryptophan depletion induced by a gelatin-based mixture impairs object memory but not affective behavior and spatial learning in the rat. Behav Brain Res 151: 53-64.

Manschreck TC, Redmond DA, Candela SF, Maher BA (1999). Effects of clozapine on psychiatric symptoms, cognition, and functional outcome in schizophrenia. J Neuropsychiatr Clin Neurosci 11: 481-489.

Matsubara S, Matsubara R, Kusumi I, Koyama T, Yamashita I (1993). Dopamine D1, D2 and serotonin2 receptor occupation by typical and atypical antipsychotic drugs in vivo.J Pharmacol Exp Therap 265: 498-508.

McGurk S, Levin ED, Butcher LL (1988). Cholinergic-dopaminergic interactions in radial-arm maze performance. Behav Neural Biol 49: 234-239.

McGurk SR (1999). The effects of clozapine on cognitive functioning in schizophrenia. J Clin Psychiatry 60(Suppl 12): 24-29.

Meltzer HY, McGurk SR (1999). The effects of clozapine, risperidone, and olanzapine on cognitive function in schizophrenia. Schizophr Bull 25: 233-255.

Michal P, Lysikova M, El-Fakahany E, Stanislav T (1999). Clozapine interaction with the M2 and M4 subtypes of muscarinic receptors. Eur J Pharmacol 376: 119-125.

Ohno M, Watanabe S (1996). Blockade of 5-HT1A receptors compensates loss of hippocampal cholinergic neurotransmission involved in working memory of rats. Brain Res 736: 180-188.

Ohno M, Yamamoto T, Watanabe S (1994). Blockade of hippocampal M1 muscarinic receptors impairs working memory performance of rats. Brain Res 650: 260-266.

Pache D, Fernandez-Perez S, Sewell R (2003). Buspirone differentially modifies short-term memory function in a combined delayed matching/non-matching to position task. Eur $J$ Pharmacol 477: 205-211.

Parada MA, Hernandez L, Puig De Parada M, Rada P, Murzi E (1997). Selective action of acute systemic clozapine on acetycholine release in the rat prefrontal cortex by reference to the nucleus accumbens and striatum. J Pharamacol Exp Therap 281: $582-588$

Park S, Coull J, McShane R, Young A, Sahakian B, Robbins T et al (1994). Tryptophan depletion in normal volunteers produces selective impairments in learning and memory. Neuropharmacology 33: 575-588.
Porter R, Lunn B, O'Brien J (2003). Effects of acute tryptophan depletion on cognitive function in Alzheimer's disease and in the healthy elderly. Psychol Med 33: 41-49.

Rezvani A, Caldwell D, Levin E (2004). Nicotine-antipsychotic drug interactions and attentional performance. Eur J Pharmacol 486: 175-182.

Sharma T, Mockler D (1998). The cognitive efficacy of atypical antipsychotics in schizophrenia. J Clin Psychopharmacol 18: 12S-19S.

Shirazi-Southall S, Rodriguez DA, Nomikos GG (2002). Effects of typical and atypical antipsychotics and receptor selective compounds on acetylcholine efflux in the hippocampus of the rat. Neuropsychopharmacology 26: 583-894.

Skarsfeldt T (1996). Differential effect of antipsychotics on place navigation of rats in the Morris water maze. A comparative study between novel and reference antipsychotics. Psychopharmacology 124: 126-133.

Stip E (1996). Memory impairment in schizophrenia: perspectives from psychopathology and pharmacotherapy. Canad J Psychiatry 41: S27-S34.

Tollefson GD (1996). Cognitive function in schizophrenic patients. J Clin Psychiatry 57(Suppl 11): 31-39.

Tsukada H, Nishiyama S, Fukumoto D, Ohba H, Sato K, Kakiuchi $\mathrm{T}$ (2004). Effects of acute acetylcholinesterase inhibition on the cerebral cholinergic neuronal system and cognitive function: functional imaging of the conscious monkey brain using animal PET in combination with microdialysis. Synapse 52: 1-10.

Umegaki H, Munoz J, Meyer R, Spangler E, Yoshimura J, Ikari H et al (2001). Involvement of dopamine $\mathrm{D}(2)$ receptors in complex maze learning and acetylcholine release in ventral hippocampus of rats. Neuroscience 103: 27-33.

Warburton E, Harrison A, Robbins T, Everitt B (1997). Contrasting effects of systemic and intracerebral infusions of the 5-HT1A receptor agonist 8-OH-DPAT on spatial short-term working memory in rats. Behav Brain Res 84: 247-258.

Weinberger DR, Gallhofer B (1997). Cognitive function in schizophrenia. Int Clin Psychopharmacol 12(Suppl 4): S29-S36.

Wilkerson A, Levin ED (1999). Ventral hippocampal dopamine D1 and D2 systems and spatial working memory in rats. Neuroscience 89: 743-749.

Wonnacott S, Irons J, Rapier C, Thorne B, Lunt GG (1989). Presynaptic modulation of transmitter release by nicotinic receptors. In: Nordberg A, Fuxe K, Holmstedt B, Sundwall A (eds). Progress in Brain Research. Elsevier Science Publishers B.V.: Amsterdam. pp 157-163.

Zhang K, Grady C, Tsapakis E, Andersen S, Tarazi F, Baldessarini $\mathrm{R}$ (2004). Regulation of working memory by dopamine D4 receptor in rats. Neuropsychopharmacology 29: 1648-1655. 